\title{
Prevalence of Celiac disease in Saudi Arabia: Meta-analysis
}

\author{
Mohammad-Ayman A Safi* \\ Associate Professor, Department of Medical Microbiology and Parasitology, King Abdulaziz University, Jeddah, Saudi Arabia
}

\begin{abstract}
Aim: Meta-analysis for the prevalence of celiac disease (CD) in Saudi Arabia (SA).

Methods: The related articles were retrieved by database and journal search. The relevant data from each article were analyzed by using the statistical package for social science (IBM SPSS Inc) and by using the Comprehensive Meta-analysis program (CMA).

Results: Only seven related articles were found; comprised of three groups: A- Four articles discussing the prevalence in the general population; Meta-analysis for these four articles showed that seroprevalence of $\mathrm{CD}$ ( one serology at least) (by fixed model ) was $2.7 \%(95 \% \mathrm{CI}=2.4-3.0)$ with no heterogeneity $\left(\mathrm{I}^{2}=0.00\right)$, while the prevalence of Biopsy-Proven CD (for two articles) was $1.4 \%(95 \% \mathrm{CI}=1.2-1.7)$ with high heterogeneity $\left(\mathrm{I}^{2}=59.3\right)$. B- One article reported the prevalence in at-risk population as $6.9 \%$ and $18.4 \%$ for the biopsy-proven $\mathrm{CD}$ and the seroprevalence respectively. C- Two letters to the editor commenting that the prevalence (1\%) reported (in one of the two articles of group A) for biopsy-proven CD was misleading due considering the patients that refused endoscopy as negative histology.

Conclusion: The current study represents the first and only meta-analysis concerning the prevalence of CD in SA. Prevalence of biopsy-proven CD (1.4\%) was lower than the seroprevalence (2.7\%), but with higher heterogeneity. Refusing endoscopy is common, that may affect the accuracy of prevalence of biopsy-proven CD, if not taken into consideration.
\end{abstract}

\section{Introduction}

Globally celiac disease's prevalence is $0.588 \%-1 \%$, [1-2] ranging from $0.33 \%$ to $2.5 \%$ [1]. Initially, prevalence of celiac disease was estimated at about $0.02 \%$ [3]. The subsequent increases in prevalence may be due to changes in diagnostic practice [4], in addition to less exposure to bacteria and other pathogens in Western environments [2]. However, data from northern America shows strong variation in CD prevalence between $0.057 \%$ in the clinically defined CD and $1 \%$ in the serologically proven CD (presence of IgA TG in blood donors) [5]. Keeping in mind that $85 \%$ of the affected subjects are undiagnosed due to variation in signs and symptoms [6], CD can be asymptomatic and because many clinicians are unfamiliar with the $\mathrm{CD}[7]$.

Studies using serology and biopsy indicate a prevalence of 0.33 $-1.06 \%$ in children $(5.66 \%$ in children of the predisposed Sahrawi people [8]) and $0.18-1.2 \%$ in adults [9]. The prevalence, among adult blood donors in Iran, Turkey and Syria was $0.60 \%, 1.15 \%$ and $1.61 \%$ respectively [10].

In Africa, Japan and China CD is rarely diagnosed [11], reflecting a very low prevalence of the genetic risk factors, such as HLA-B8 [12]. But similar risk was reported in Indians and Western Caucasians [10].

Concerning, the primary care populations with gastrointestinal symptoms, the prevalence was about 3\% [13].

Concerning the At-risk groups, the prevalence ranging from 5\% to $10 \%$, include Down and Turner syndromes, type 1 diabetes, and autoimmune thyroid disease [3]. In the USA, the prevalence was found to be $0.75 \%$ in not-at-risk groups, $1.8 \%$ in symptomatic people, $2.6 \%$ in second-degree relatives and $4.5 \%$ in first-degree relatives, with similar profile in Europe [10].

So far, only seven articles concerning the CD prevalence in SA were retrieved by a comprehensive database and journal search [14]. Here, we present description and Meta-analysis for the literatures concerning the prevalence of celiac disease in Saudi Arabia.

\section{Methods}

\section{Strategy for systematic search and study selection}

The related articles were retrieved by database and journal search. The selection process (inclusion/exclusion) of the pertinent studies was described in detail in our previous analytical review in this journal [14]. Using different key words ("celiac disease in Saudi Arabia", "celiac disease in Saudi children " and "prevalence of celiac disease in Saudi Arabia"), an electronic literature search was conducted via PubMed (US National Library of Medicine, with no specific period), Ovid, EBSCO and scholar Google; in addition to few related articles obtained through the library of king Fahd research centre of King Abdulaziz University, and directly from the editorial department of the two local journals (Saudi Journal of Internal Medicine and Journal of King Abdulaziz University Medical Science. All the retrieved articles were checked for matching (duplication) via their titles, author(s) and year of publication. Selection of the pertinent studies was achieved via two processes. After matching (for duplication), articles that were concerned with celiac disease in Saudi Arabia were selected (first selection) and

${ }^{\star}$ Correspondence to: Mohammad-Ayman A Safi, Associate Professor of Immunology, Department of Medical Microbiology and Parasitology, Faculty of Medicine, King Abdul-Aziz University, PO Box 80205, Jeddah 21589, Kingdom of Saudi Arabia, Tel: +966 (12) 6400000. Ext 21116, Fax: +966 (12) 6403749 , E-mail: aymansafi3@hotmail.com

Key words: Saudi Arabia, Celiac disease prevalence, Coeliac disease prevalence, Celiac disease epidemiology, Celiac disease seroprevalence, Celiac disease metaanalysis, Heterogeneity

Received: July 24, 2018; Accepted: August 14, 2018; Published: August 16, 2018 
their data were recorded using statistical package for social science (IBM SPSS Inc), Version 20. Chicago. Articles that are concerned with the prevalence discipline were further selected (second selection) and kept as a separate SPSS file that was used in this study.

\section{Statistical analysis}

Analysis of data was performed using statistical package for social science (IBM SPSS Inc), Version 20, Chicago; and by using the Comprehensive Meta-analysis program (CMA), Version 3. software program (Biostat, USA). Heterogeneity was calculated using I squared $\left(\mathrm{I}^{2}\right) . \mathrm{I}^{2}$ values of $0 \%,<25 \%, 25 \%$ to $49 \%$ and $>50 \%$ denoted no, low, moderate, and high heterogeneity, respectively. The results were illustrated in tabulated form, diagrams and figures.

\section{Results}

Selection and characterization of the pertinent studies (Figure 1 \& Table 1)

As described above, after matching (for duplication), data from articles (74 articles) that were concerned with celiac disease in Saudi Arabia (Figure 1) were recorded using statistical package for social science (IBM SPSS Inc), Version 20. Chicago. Articles that are concerned with celiac prevalence ( 7 articles) were selected and kept as a separate SPSS file that was used in this study. Characterization of these studies with their serological/biopsy pattern are shown in Table 1. The seven related articles were comprised of three groups (Figure 1): A- Four articles discussing the prevalence in the general population

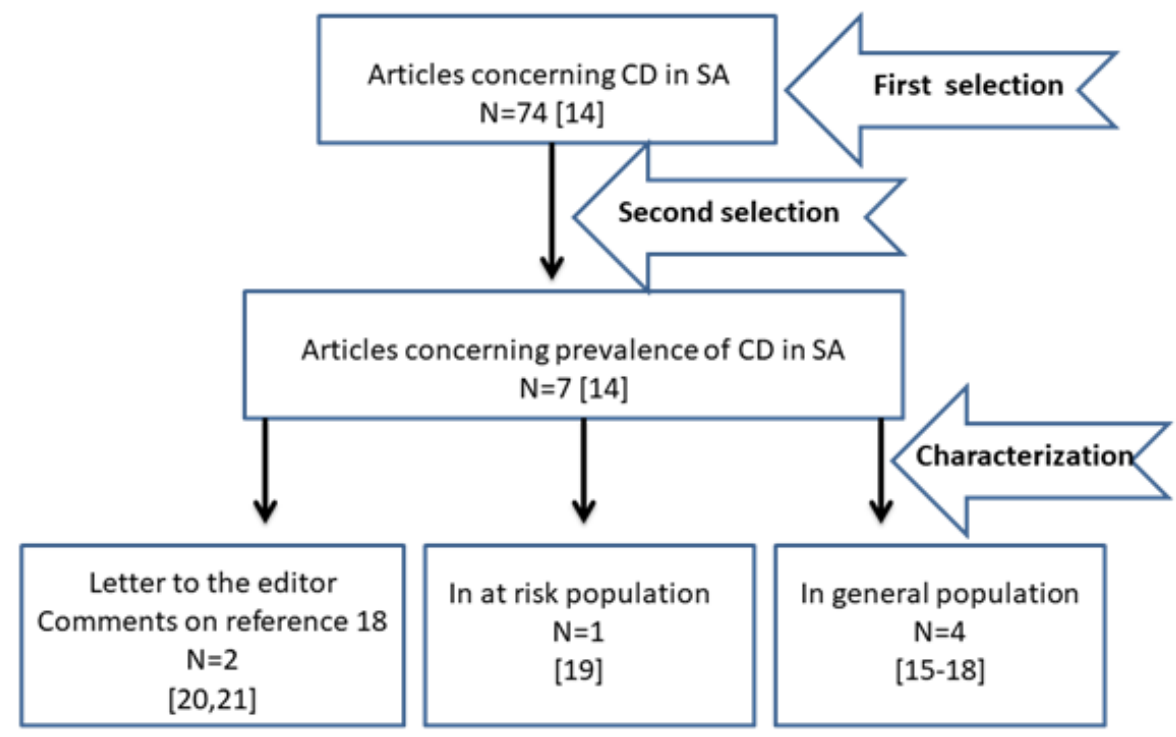

Figure 1. PRISMA flow-diagram showing the selection process of pertinent studies

Table 1. Characterization of identified studies on prevalence of celiac disease (CD) in Saudi Arabia, with their serological/biopsy pattern*

\begin{tabular}{|c|c|c|c|c|c|c|}
\hline & $\begin{array}{l}\text { Author(s) and date } \\
\text { of article [ref] } \\
\text { (region(s)) }\end{array}$ & $\begin{array}{l}\text { Age ranges } \\
\text { (mean) } \\
\text { /year }\end{array}$ & Cohort & $\begin{array}{l}\text { Seroprevalence } \\
(\mathbf{F} / \mathbf{M}) \\
(\mathbf{1 5 6} / \mathbf{8 2}=\mathbf{1 . 9})\end{array}$ & Prevalence of Biopsy-Proven CD & Serology with/without biopsy? \\
\hline 1 & $\begin{array}{l}\text { Al-Hussaini A, et al. } \\
2017[15 \\
\text { (Riyadh ) }\end{array}$ & 6-15 & $\begin{array}{l}7930 \\
\text { Students }\end{array}$ & $\begin{array}{l}221 / 7930=2.78 \\
(81 / 38)\end{array}$ & $\begin{array}{l}\text { Biopsy and/or ESPHAN criteria } \\
(119 / 7930=1.5 \%)\end{array}$ & TTG-IgA, EMA-IgA, and biopsy \\
\hline 2 & $\begin{array}{l}\text { Khayyat YM. } 2012 \\
{[16]} \\
\text { (Blood bank/Jeddah) }\end{array}$ & $\begin{array}{l}14-78 \\
(35)\end{array}$ & $\begin{array}{l}204 \\
\text { (Blood bank) }\end{array}$ & $\begin{array}{l}3 / 204=1.5 \\
(1 / 2)\end{array}$ & Not performed & TTG-IgA \\
\hline 3 & $\begin{array}{l}\text { Aljebreen AM, et al. } \\
2013 \text { [17] } \\
\text { Aseer, Al-Qaseem, } \\
\text { Madinah }\end{array}$ & $16-18$ & $\begin{array}{l}1167 \\
\text { students from } \\
\text { the } 10 \text { th to } \\
12 \text { th grades }\end{array}$ & $\begin{array}{l}26 / 1167=2.2 \% \\
(17 / 9)\end{array}$ & Biopsies were not available & IgA and IgG EMA \\
\hline 4 & $\begin{array}{l}\text { A1 Hatlani MM. } \\
2016[18] \\
\text { Students } \\
\text { Eastern Province }\end{array}$ & $6-18$ & $\begin{array}{l}1141 \\
\text { Students }\end{array}$ & $\begin{array}{l}32 / 1141=3 \% \\
(17 / 15)\end{array}$ & $\begin{array}{l}1 \%(\text { misleading }[20,21]) \\
\text {-Cohort without those who refused } \\
\text { biopsy }(1141-22=1119) \rightarrow \\
\text { Prevalence }(10 / 1119=0.9 \%)\end{array}$ & $\begin{array}{l}\text { IgA-tTG and IgG-tTG and biopsy } \\
\text { Biopsy was performed for } 10 \text { of } \\
\text { whom were antibody positive. All } 10 \\
\text { were biopsy positive. }\end{array}$ \\
\hline 5 & $\begin{array}{l}\text { Al-Hakami AM } \\
2016[19] \\
\text { Asseer }\end{array}$ & $1-79$ & $\begin{array}{l}315 \\
\text { Aseer Central } \\
\text { Hospital }\end{array}$ & $\begin{array}{l}58 / 315=18.4 \\
(40 / 18)\end{array}$ & $\begin{array}{l}6.9 \% \text { (misleading) } \\
\text { Cohort without those who refuse } \\
\text { biopsy }(315-18=287) \\
\rightarrow \text { Prevalence }(22 / 297=7.4 \%) \\
\text { (40 with endoscopy and } 22 \text { positive) }\end{array}$ & $\begin{array}{l}\text { tTG-IgA, EMA-IgA, and biopsy } \\
\text { Only } 40 \text { (whom tested positive for } \\
\text { IgA-tTG) tested for biopsy }\end{array}$ \\
\hline 6 & $\begin{array}{l}\text { Al-Mendalawi MD } \\
2016[20]\end{array}$ & $\begin{array}{l}\text { None/ } \\
\text { comments }\end{array}$ & $\begin{array}{l}\text { None/ } \\
\text { comments }\end{array}$ & None/comments & None/comments & None/comments \\
\hline 7 & $\begin{array}{l}\text { Almadi MA, } \\
\text { Aljebreen AM. } \\
2016[21]\end{array}$ & $\begin{array}{l}\text { None/ } \\
\text { comments }\end{array}$ & $\begin{array}{l}\text { None/ } \\
\text { comments }\end{array}$ & None/comments & None/comments & None/comments \\
\hline
\end{tabular}

*Studies 1-4 were in general population and were considered for the Meta-analysis; study 5 was in at risk population; studies 6 and 7 were letters to the editor with comments on study 4 . 
(articles [15-18]), B- One article reported the prevalence in at-risk population (article [19]) and C- Two letters to the editor (articles [20] and [21]). Age wise, these studies covered different age groups (Table 1): children and adolescents (6-15 years) (Table 1; article 1); adolescents and adults (14-78 years) (Table 1; article 2); adolescents (16-18years) (Table 1; article 3); children and adolescents (6-18 years) (Table 1; article 4); children and adolescents and adults (1-79 years) (Table 1; article 5). Table 1 also illustrates the different cohorts and prevalence for both seropositivity and biopsy-proven conditions.

\section{Cohort for prevalence of biopsy-proven CD}

Refusing endoscopy by some patients was a common feature which was found in two studies [18,19]. Al Hatlani [18] reported a seroprevalence of $3 \%(32 / 1141=2.8)$ and that only 10 of the 32 who were seropositive underwent an endoscopy with positive histological findings and with prevalence of Biopsy-Proven CD of 1\% (10/1141= 0.87\%). However, Al-Mendalawi [20] and Almadi [21] commented that the prevalence (1\%) reported for biopsy-proven CD was underestimated due to considering the patients that refused endoscopy as negative histology [21]. Likewise, Al-Hakami 2016 [19] reported a seroprevalence of $18.4 \%(58 / 315)$ and that only 40 of the 58 who were seropositive underwent an endoscopy (18 refused) of which 22 were biopsy-positive with a prevalence of Biopsy-Proven CD of $6.9 \%$ (22/315); which would also be misleading due to the same reason, and due to the fact that the sensitivity and specificity are high for both the tTG-IgA test (98\% and 98\% respectively) and for EMA test (95\% and $99 \%$ respectively) [22,23]. It would sound more logically if the 18 patients (who refused endoscopy) were omitted from the total number $(315-18=297)$ and calculate the prevalence accordingly which would be $7.4 \%(22 / 297)$. Similarly, for the 22 who refused endoscopy [18]; the cohort would be $(1141-22=1119)$ and the rate would be $(10 / 1119=$ $0.9 \%)$.

Thus, for the prevalence of Biopsy-Proven CD in both articles (table 1 ; articles 4 and 5) we used the cohort after detracting those that refused endoscopy (22 in article [18] and 18 in article [19]). The used cohorts were 1119 and 297 respectively.

\section{Statistical analysis}

SPSS analysis: Table 2 illustrates the cohort's ranges, rates and means for both seropositivity and biopsy-proven positivity. For the general population (articles 1-4 in Table 1); cohort's range was $204-7930$ with a mean of 2610 and standard deviation of 3574.51 (Table 2). The mean of seropositivity in the general population (articles 1-4 in Table 1) was 70.00 individual with a range of 3-221 and standard deviation of 101.00. Cohort after detracting those that refused endoscopy (in article 4 in Table 1) was 1119. Thus, the cohorts' mean for studies with prevalence of the biopsy-proven CD (articles 1 and 4 in Table 1) was 4524 (1119 and 7930) with standard deviation of 4816 (Table 2); the mean of biopsy positivity in this type of cohort (for articles land 4 in Table 1) was 64.00 individual (10 and 118) with standard deviation of 76 (Table 2). Rate of seropositivity was $2.68 \%(70 / 2610)$, while the rate of biopsy-proven positivity was $1.4 \%(64 / 4524)$.

\section{Meta-analysis}

Meta-analysis was performed using the Comprehensive Metaanalysis program (CMA). Meta-analysis was performed for the four articles discussing the prevalence in the general population (articles 1-4; Table 1). The Meta-analysis of seropositivity prevalence (Tables 1a and $1 \mathrm{~b}$; \& Figures $1 \mathrm{a}$ and $1 \mathrm{~b}$ ) showed that CD prevalence (by fixed model) for serologically proven CD (one serology at least) was $2.7 \%$ $(95 \% \mathrm{CI}=2.4-3.1)$ with no heterogeneity $\left(\mathrm{I}^{2}=0.00\right)$. While Metaanalysis for prevalence of biopsy-proven positivity (for two articles) (Tables $2 \mathrm{a}$ and $2 \mathrm{~b} \&$ Figure $2 \mathrm{a}$ and $2 \mathrm{~b}$ ) was $1.4 \%(95 \% \mathrm{CI}=1.2-1.7)$ with high heterogeneity $\left(I^{2}=59.3\right)$.

\section{Discussion}

The Meta-analysis (for four articles) showed that seroprevalence of CD in SA (one serology at least) (by fixed model) is $2.7 \%$ (95\% CI $=2.4 \%-3.0 \%)$ with no heterogeneity $\left(\mathrm{I}^{2}=0.00\right)$, while the prevalence of Biopsy-Proven CD (for two articles) is $1.4 \%$ (95\% CI $=1.2 \%-1.7 \%$ ) with high heterogeneity $\left(\mathrm{I}^{2}=59.3\right)$.

In our study, the seroprevalence $(2.7 \%)$ was higher than the global pooled seroprevalence reported by the meta-analysis of Singh et al. [24]

Table 2. Mean of seropositivity* and biopsy- proven positivity**

\begin{tabular}{|c|c|c|c|c|c|}
\hline & & Mean & Minimum & Maximum & Number of studies \\
\hline \multirow{2}{*}{ Seropositivity CD } & seropositivity & 70.25 & 3.00 & 221.00 & 101.25 \\
\cline { 2 - 6 } & Cohort & 2610.50 & 204.00 & 7930.00 & 3574.51 \\
\hline \multirow{2}{*}{ Biopsy-proven CD } & Biopsy positivity & 64.00 & 10.00 & 118.00 & 76.36 \\
\cline { 2 - 6 } & Cohort & 4524.50 & 1119.00 & 7930.00 & 4816.10 \\
\hline
\end{tabular}

*Rate of seropositivity $(70 / 2610=2.68 \%)$

** Rate of biopsy-proven positivity $(64 / 4524=1.4 \%)$

Table 1a. Data for Meta-analysis of seropositivity prevalence

\begin{tabular}{|c|c|c|c|c|c|}
\hline & Study name & $\begin{array}{c}\text { Event } \\
\text { rate }\end{array}$ & $\begin{array}{c}\text { Sample } \\
\text { size }\end{array}$ & $\begin{array}{c}\text { Event } \\
\text { rate }\end{array}$ & Standard Error \\
\hline $\mathbf{1}$ & Al-Hussaini A, et al. 2017 & 0.028 & 7930 & 0.028 & -3.547 \\
\hline $\mathbf{2}$ & Khayyat YM 2012 & 0.015 & 204 & 0.015 & -4.185 \\
\hline $\mathbf{3}$ & Al- Jebreen AM, et al. 2013 & 0.022 & 1167 & 0.022 & -3.794 \\
\hline $\mathbf{4}$ & Al Hatlani MM 2016 & 0.030 & 1141 & 0.030 & -0.576 \\
\hline
\end{tabular}

Table 1b. Prevalence (by fixed and random models) with the heterogeneity

\begin{tabular}{|c|c|c|c|c|c|c|c|c|c|c|c|c|c|c|}
\hline \multirow[t]{2}{*}{ Model } & \multirow[b]{2}{*}{$\begin{array}{c}\text { Number of } \\
\text { studies }\end{array}$} & \multicolumn{3}{|c|}{ Effect size and $95 \%$ internal } & \multicolumn{2}{|c|}{ Test of null (2-Tail) } & \multicolumn{4}{|c|}{ Heterogeneity } & \multicolumn{4}{|c|}{ Tau - squared } \\
\hline & & $\begin{array}{c}\text { Point } \\
\text { estimate }\end{array}$ & $\begin{array}{c}\text { Lower } \\
\text { limit }\end{array}$ & $\begin{array}{l}\text { Upper } \\
\text { limit }\end{array}$ & Z-value & P-value & Q-value & $\mathrm{Df}(\mathrm{Q})$ & P-value & I- Squared & $\begin{array}{c}\text { Tau } \\
\text { Squared }\end{array}$ & $\begin{array}{c}\text { Standard } \\
\text { Error }\end{array}$ & Variance & Tau \\
\hline Fixed & 4 & 0.027 & 0.024 & 0.031 & -59.399 & 0.000 & 2.808 & 3 & 0,422 & 0.00 & 0.00 & 0.024 & 0.001 & 0.00 \\
\hline Random & 4 & 0.027 & 0.024 & 0.031 & -59.399 & 0.000 & & & & & & & & \\
\hline
\end{tabular}




\begin{tabular}{|c|c|c|c|c|c|c|c|c|c|c|c|c|c|}
\hline \multirow[t]{2}{*}{ Model } & \multirow{2}{*}{$\begin{array}{l}\text { Statistics for } \\
\text { each study } \\
\text { Event rate }\end{array}$} & \multirow[t]{2}{*}{ Study name } & \multicolumn{4}{|c|}{ Statistics for each study } & \multicolumn{5}{|c|}{ Event rate and $95 \% \mathrm{Cl}$} & \multirow{2}{*}{$\begin{array}{l}\text { Weight (Fixed) } \\
\text { Relative weight }\end{array}$} & \multirow{2}{*}{$\begin{array}{l}\text { Weight (Random) } \\
\text { Relative weight }\end{array}$} \\
\hline & & & Lower limit & Upper limit & ZValue & $\mathrm{p}$ Value & -0.05 & -0.03 & 0.00 & 0.03 & 0.05 & & \\
\hline & $\begin{array}{l}0.028 \\
0.015 \\
0.022 \\
0.030\end{array}$ & $\begin{array}{l}\text { Al-Hussaini A etal } 2017 \\
\text { Khayyat YM } 2012 \\
\text { Al Jebreen AM etal } 2013 \\
\text { Al Hatlani MM } 2016\end{array}$ & $\begin{array}{l}0.025 \\
0.005 \\
0.015 \\
0.022\end{array}$ & $\begin{array}{l}0.032 \\
0.045 \\
0.032 \\
0.042\end{array}$ & $\begin{array}{r}-52.111 \\
-7.265 \\
-19.014 \\
-20.030\end{array}$ & $\begin{array}{l}0.000 \\
0.000 \\
0.000 \\
0.000\end{array}$ & & & & \begin{tabular}{l|l} 
& + \\
+ & \\
+1
\end{tabular} & & $\begin{array}{r}77.87 \\
1.09 \mid \\
9.06 \mid \\
11.98\end{array}$ & $\begin{array}{r}77.87 \\
1.09 \mid \\
9.06 \mid \\
11.98\end{array}$ \\
\hline $\begin{array}{l}\text { Fixed } \\
\text { Random }\end{array}$ & $\begin{array}{l}0.027 \\
0.027\end{array}$ & & $\begin{array}{l}0.024 \\
0.024\end{array}$ & $\begin{array}{l}0.031 \\
0.031\end{array}$ & $\begin{array}{l}-59.399 \\
-59.399\end{array}$ & $\begin{array}{l}0.000 \\
0.000\end{array}$ & & & & + & & & \\
\hline
\end{tabular}

Figure 1a. Prevalence (by fixed and random models) with statistics and relative weight for each study

\section{Meta Analysis}

\begin{tabular}{|c|c|c|c|c|c|c|c|c|c|c|}
\hline \multirow[t]{2}{*}{ Model } & \multirow[b]{2}{*}{$\begin{array}{c}\text { Event } \\
\text { rate }\end{array}$} & \multirow[t]{2}{*}{ Study name } & \multicolumn{4}{|c|}{ Statistics for each study } & & \multicolumn{3}{|c|}{ Event rate and $95 \% \mathrm{Cl}$} \\
\hline & & & $\begin{array}{c}\text { Lower } \\
\text { limit }\end{array}$ & $\begin{array}{c}\text { Upper } \\
\text { limit }\end{array}$ & Z-Value & p-Value & & & & \\
\hline & 0.028 & Al-Hussaini A etal 2017 & 0.025 & 0.032 & -52.111 & 0.000 & & I & & \\
\hline & 0.015 & Khayyat YM 2012 & 0.005 & 0.045 & -7.265 & 0.000 & & & & \\
\hline & 0.022 & Al-Jebreen AM etal 2013 & 0.015 & 0.032 & -19.014 & 0.000 & & & & \\
\hline & 0.030 & Al Hatlani MM 2016 & 0.022 & 0.042 & -20.030 & 0.000 & & & & \\
\hline \multirow[t]{2}{*}{ Fixed } & 0.027 & & 0.024 & 0.031 & -59.399 & 0.000 & & & & \\
\hline & & & & & & & -0.05 & -0.03 & 0.00 & 0.03 \\
\hline
\end{tabular}

Figure 1b. Forest plot of the Meta analysis of seropositivity prevalence.

Table 2a. Data for Meta-analysis for prevalence of Biopsy proven CD

\begin{tabular}{|c|c|c|c|c|c|c|}
\hline & Study name & $\begin{array}{c}\text { Event } \\
\text { rate }\end{array}$ & $\begin{array}{c}\text { Sample } \\
\text { size }\end{array}$ & $\begin{array}{c}\text { Event } \\
\text { rate }\end{array}$ & Standard Error \\
\hline $\mathbf{1}$ & Al-Hussaini A et al.2017 & 0.015 & 7930 & 0.015 & -4.185 \\
\hline $\mathbf{2}$ & Al Hatlani MM 2016 & 0.009 & 1119 & 0.009 & -0.092 \\
\hline
\end{tabular}

Table 2b. Prevalence (by fixed and random models) with the heterogeneity between studies

\begin{tabular}{|c|c|c|c|c|c|c|c|c|c|c|c|c|c|c|}
\hline \multirow[t]{2}{*}{ Model } & \multirow[b]{2}{*}{$\begin{array}{c}\text { Number } \\
\text { of studies }\end{array}$} & \multicolumn{3}{|c|}{ Effect size and $95 \%$ internal } & \multicolumn{2}{|c|}{ Test of null (2-Tail) } & \multicolumn{4}{|c|}{ Heterogeneity } & \multicolumn{4}{|c|}{ Tau - squared } \\
\hline & & $\begin{array}{c}\text { Point } \\
\text { estimate }\end{array}$ & $\begin{array}{c}\text { Lower } \\
\text { limit }\end{array}$ & $\begin{array}{l}\text { Upper } \\
\text { limit }\end{array}$ & Z-value & P-value & Q-value & Df $(Q)$ & P-value & I- Squared & $\begin{array}{c}\text { Tau } \\
\text { Squared }\end{array}$ & $\begin{array}{c}\text { Standard } \\
\text { Error }\end{array}$ & Variance & Tau \\
\hline Fixed & 2 & 0.014 & 0.012 & 0.017 & -47.643 & 0.000 & 2.457 & 1 & 0.117 & 59.305 & 0.079 & 0.139 & 0.036 & 0281 \\
\hline Random & 2 & 0.013 & 0.008 & 0.020 & -17.937 & 0.000 & & & & & & & & \\
\hline
\end{tabular}

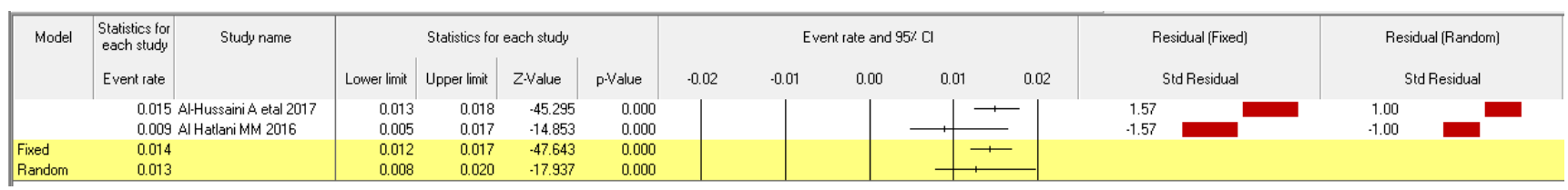

Figure 2a. Prevalence (by fixed and random models) with statistics and relative weight for each study

Meta Analysis

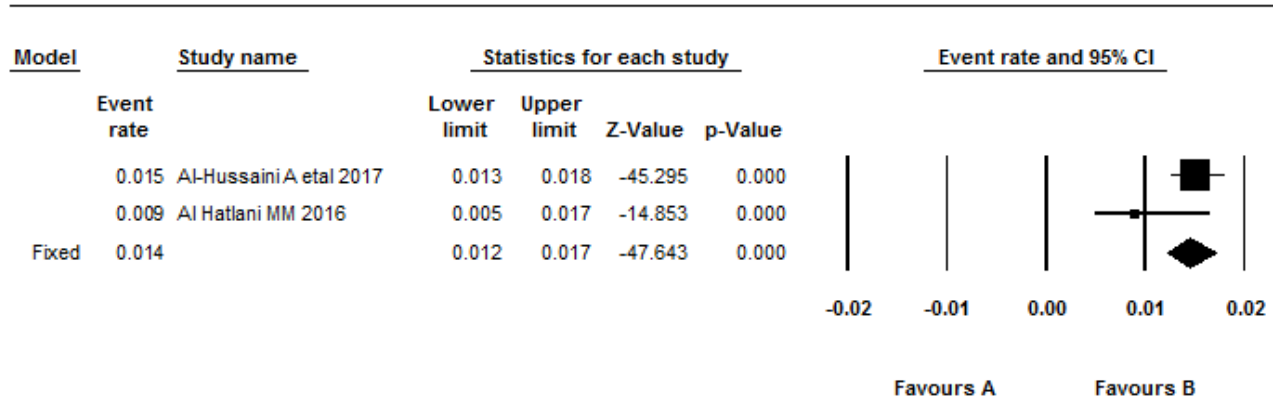

Figure 2b. Forest plot of the Meta-analysis for the prevalence of Biopsy proven positinity 
as $1.4 \%$ (95\% CI, $1.1 \%-1.7 \%)$. In our study the prevalence of biopsyproven CD (1.4\%) was also higher than the global pooled prevalence of biopsy-proven CD reported by Singh, et al. [24] as $0.7 \%$ and by Biagi et al. [25] (0.58\%).

The present meta-analysis confirms that the seropositive females are 1.9 times more common than males.

Some limitation was noted. Including the limited number of studies; only four articles for meta-analysis, two studies of them only reported the seroprevalence, but not the prevalence of the biopsy proven, only few studies (two) reported prevalence of biopsy-proven $\mathrm{CD}$, which could not be established properly, mostly because $30-60 \%$ of seropositive individuals refused to undergo a biopsy. One article [19] discussed the prevalence in at risk population [19], with seroprevalence of $18.4 \%$ (58/315) and 6.9\% (22/315) for prevalence of Biopsy-Proven $\mathrm{CD}$, which would be misleading due to considering those who refuse endoscopy as biopsy negative histology, in spite of the fact that the sensitivity and specificity are high for both used tests, tTG-IgA test (98\% and $98 \%$ respectively) and for EMA test (95\% and $99 \%$ respectively) [22,23]. Thus, for the prevalence of Biopsy-Proven CD we used the cohort after detracting those that refused endoscopy (18 seropositive individual) in article [19] which gave a prevalence of $7.4 \%$. However, concerning the At-risk groups, the global prevalence ranging from $5 \%$ to $10 \%$, include Down and Turner syndromes, type 1 diabetes, and autoimmune thyroid disease [3]. In the USA, the prevalence was found to be $0.75 \%$ in not-at-risk groups, $1.8 \%$ in symptomatic people, $2.6 \%$ in second-degree relatives and $4.5 \%$ in first-degree relatives, with similar profile in Europe [10]. It is worth mentioning, that the articles discussing Down syndrome, type 1 Diabetes Mellitus and Short status [14] will be separately analyzed by Meta-analysis.

The highest prevalence was in Al-Qaseem region (3.2\%) (8/252) [17] and the Eastern Province (3\%) (32/1141) [18], and the least prevalence in Riyadh and Jeddah $(1.5 \%)[15,16]$. The factors influencing the regional difference in prevalence of $\mathrm{CD}$ were shown to include the HLA and non-HLA genes, patterns of wheat consumption, age at wheat introduction, practices of infant feeding, gastrointestinal infections, the use of antibiotic and proton-pump inhibitor use, and caesarian section rates [26]. It is recommended to search for these factors in different regions in SA, particularly the population prevalence of the HLA-DQ2 haplotype and wheat consumption. These two factors, for examples, are significantly lower in sub-Saharan Africa compared with Northern Africa [27]. However, recently an interesting study was appeared in SA in this concern [28] which reported one of the highest frequencies of CD-predisposing HLA-DQ genotypes among healthy general populations $(52.7 \%)$ worldwide.

\section{Conclusion}

The current study represents the first and only meta-analysis concerning the prevalence of CD in SA. Prevalence of biopsy-proven $\mathrm{CD}(1.4 \%)$ was lower than the seroprevalence (2.7\%), but with higher heterogeneity. Refusing endoscopy is common, that may affect the accuracy of prevalence of biopsy-proven $\mathrm{CD}$; a point which must be taken into consideration.

\section{Ethical approval}

The collected data were part of a retrospective literature review and analysis, thus a written ethical approval was not obtained before commencing the study.

\section{Disclosures}

The current study was not funded or supported by any drug company. This paper is unique and is not under consideration by any other publication and has not been published elsewhere.

\section{Conflicts of Interest}

The author declares no conflicts of interest.

\section{Financial support and sponsorship}

Nil

\section{References}

1. Fasano A, Catassi C (2012) Clinical practice. Celiac disease. N Engl J Med 367: 24192426. [Crossref]

2. Lebwohl B, Ludvigsson JF, Green PH (2015) Celiac disease and non-celiac gluten sensitivity. BMJ 351: h4347. [Crossref]

3. Barker JM, Liu E (2008) Celiac disease: pathophysiology, clinical manifestations, and associated autoimmune conditions. Adv Pediatr 55: 349-365. [Crossref]

4. Leeds JS, Hopper AD, Sanders DS (2008) Coeliac disease. Br Med Bull 88: 157-170. [Crossref]

5. Rewers M (2005) Epidemiology of celiac disease: what are the prevalence, incidence, and progression of celiac disease? Gastroenterology 128: S47-S51. [Crossref]

6. Guandalini S, Assiri A (2014) Celiac disease: a review. JAMA Pediatrics 168: 272-278 [Crossref]

7. Zipser RD, Farid M, Baisch D, Patel B, Patel D (2005) Physician awareness of celiac disease: a need for further education. J Gen Intern Med 20: 644-646. [Crossref]

8. Catassi C, Rätsch IM, Gandolfi L, Pratesi R, Fabiani E, et al. (1999) "Why is coeliac disease endemic in the people of the Sahara?" Lancet 354: 647-648. [Crossref]

9. van Heel DA, West J (2006) Recent advances in coeliac disease. Gut 55: 1037-1046. [Crossref]

10. Gujral N, Freeman HJ, Thomson AB (2012) Celiac disease: prevalence, diagnosis, pathogenesis and treatment. World J Gastroenterol 18: 6036-6059. [Crossref]

11. Houlston RS, Ford D (1996) Genetics of coeliac disease. QJM 89: 737-743. [Crossref]

12. Buchanan N (1987) Child and Adolescent Health for Practitioners. Williams \& Wilkins 164.

13. van der Windt DA, Jellema P, Mulder CJ, Kneepkens CM, van der Horst HE (2010) Diagnostic testing for celiac disease among patients with abdominal symptoms: a systematic review. JAMA 303: 1738-1746. [Crossref]

14. Safi M AA, Safi H MA (2018) Celiac Disease and its Serological Pattern in Saudi Arabia: A Systematic Review. Glob Vaccines Immunol 3.

15. Al-Hussaini A, Troncone R, Khormi M, AlTuraiki M, Alkhamis W, et al. (2017) Mass Screening for Celiac Disease Among School-aged Children: Toward Exploring Celiac Iceberg in Saudi Arabia. J Pediatr Gastroenterol Nutr 65: 646-651. [Crossref]

16. Khayyat YM (2012) Serologic markers of gluten sensitivity in a healthy population from the western region of Saudi Arabia. Saudi J Gastroenterol 18: 23-25. [Crossref]

17. Aljebreen AM, Almadi MA, Alhammad A, Al Faleh FZ (2013) Seroprevalence of celiac disease among healthy adolescents in Saudi Arabia. World J Gastroenterol 19: 2374-2378. [Crossref]

18. Al Hatlani MM (2015) Prevalence of celiac disease among symptom-free children from the Eastern Province of Saudi Arabia. Saudi J Gastroenterol 21: 367-371. [Crossref]

19. Al-Hakami AM (2016) Seroprevalence of coeliac disease in at-risk subjects at the main tertiary hospital, southwest of Saudi Arabia. Arab J Gastroenterol 17: 41-44. [Crossref]

20. Al-Mendalawi MD (2016) Prevalence of celiac disease in Saudi children: Is it underestimated? Saudi J Gastroenterol 22: 83. [Crossref]

21. Almadi MA, Aljebreen AM (2016) Celiac disease among symptom-free children-more than what is expected. Saudi J Gastroenterol 22: 82. [Crossref]

22. Leffler DA, Schuppan D (2010) Update on serologic testing in celiac disease. Am J Gastroenterol 105: 2520-2524. [Crossref] 
23. Nandiwada SL, Tebo AE (2013) Testing for antireticulin antibodies in patients with celiac disease is obsolete: a review of recommendations for serologic screening and the literature. Clin Vaccine Immunol 20: 447-451. [Crossref]

24. Singh P, Arora A, Strand TA, Leffler DA, Catassi C, et al. (2018) Global Prevalence of Celiac Disease: Systematic Review and Meta-analysis. Clin Gastroenterol Hepatol 16: 823-836. [Crossref]

25. Biagi F, Klersy C, Balduzzi D, Corazza GR (2010) Are we not over-estimating the prevalence of coeliac disease in the general population? Ann Med 42: 557-561. [Crossref]
26. Lebwohl B, Murray JA, Verdú EF, Crowe SE, Dennis M, et al. (216) Gluten introduction, breastfeeding, and celiac disease: back to the drawing board. Am J Gastroenterol 111: 12-14. [Crossref]

27. Lionetti E, Catassi C (2014) Co-localization of gluten consumption and HLA-DQ2 and -DQ8 genotypes, a clue to the history of celiac disease. Dig Liver Dis 46: 10571063.

28. Al-Hussaini A, Alharthi H, Osman A, Eltayeb-Elsheikh N, Chentoufi A (2018) Genetic susceptibility for celiac disease is highly prevalent in the Saudi population. Saudi $J$ Gastroenterol [Crossref]

Copyright: (O2018 Safi M-A. This is an open-access article distributed under the terms of the Creative Commons Attribution License, which permits unrestricted use, distribution, and reproduction in any medium, provided the original author and source are credited. 